\title{
Thoracoscopic, histological, and clinical findings in nine case of rheumatoid pleural effusion
}

\author{
P FAURSCHOU, D FRANCIS, P FAARUP \\ From Medical Department $P$ and the Department of Pathology, Bispebjerg Hospital, Copenhagen, and the \\ University Institute of Pathology, Copenhagen, Denmark
}

\begin{abstract}
A characteristic thoracoscopic picture of a granular parietal pleural surface was found in nine patients with rheumatoid pleurisy. Characteristic changes could be identified histopathologically in material obtained by biopsy. The rheumatoid pleural effusion resolved within an average of 14 months and no serious complications developed after the pleurisy. It is concluded that in rheumatoid pleural effusion a positive diagnosis can be made by thoracoscopy, preferably supported by the identification of microscopic structural changes in the parietal pleura.
\end{abstract}

Rheumatoid pleurisy is at present a diagnosis reached only by exclusion. ${ }^{1-3}$ Certain biochemical changes in the rheumatoid pleural effusion, such as low glucose and high lactate dehydrogenase concentrations, are of diagnostic help but are not specific, $^{24}$ nor is the finding of the so called rheumatoid arthritis cells (RA cells). ${ }^{45}$

In rheumatoid pleurisy "blind pleural biopsies" most often show non-specific inflammatory changes, and in most cases the purpose of the biopsy is to exclude other diseases. ${ }^{136-8}$ Specific rheumatoid lesions in the pleura corresponding to those found in subcutaneous rheumatoid nodules are seldom seen. $^{39-11}$ The subsequent clinical course of the disease seems to vary greatly ${ }^{1-3}$

The aim of the present study was to describe the thoracoscopic appearance and the histopathological features of the pleural surface together with the clinical course in nine cases of rheumatoid pleurisy.

\section{Material and methods}

Twelve hundred thoracoscopies were performed during 10 years. In nine of the patients the pleural surface showed a unique granular appearance. Three parietal pleural biopsy specimens on average were taken from each patient and one visceral biopsy specimen was taken in four of the patients; pleural fluid was examined in all. Seven of the nine

Address for reprint requests: Dr P Faurschou, Medical Department P, Bispebjerg Hospital, Copenhagen NV, DK-2400, Denmark.

Accepted 3 December 1984 patients had classical rheumatoid arthritis (according to the American Rheumatism Association criteria $^{12}$ ) with rheumatoid pleural effusion, and two had monosymptomatic pleurisy as the first manifestation of the rheumatoid disease, which presented as definite rheumatoid arthritis one and three months later respectively (table). There were seven men and two women, mean age 54 years. The clinical course was in each case ascertained from the case records, personal interview, and examination and in some patients from the death certificates and necropsy reports. The definition used for remission of arthritis was that a patient should have had no treatment and been free from complaints related to the joints.

Thoracocentesis with air insufflation and thoracoscopy were performed under local anesthesia. The thoracoscope used was a rigid fibreoptic scope (Storz), and the biopsy specimens were taken with a spoon forceps.

Thoracoscopic biopsy specimens were formalin fixed and stained with haematoxylin eosin and van Giesen Hansen. The pleural fluid was examined for glucose, protein, lactate dehydrogenase, RA cells, crystals, tumour cells, and bacteria.

\section{Results}

\section{THORACOSCOPIC FINDINGS}

In all cases the visceral pleural surface showed a varying degree of non-specific inflammation. In contrast, the parietal pleural surface had in each case a "gritty" or frozen appearance. The surface looked slightly inflamed and thickened with numerous small vesicles or granules of about $0.5 \mathrm{~mm}$ in diameter 
Selected laboratory and clinical data on patients with rheumatoid arthritis and rheumatoid pleural effusions

\begin{tabular}{|c|c|c|c|c|c|c|c|c|c|}
\hline \multirow{2}{*}{$\begin{array}{l}\text { Patient } \\
\text { No and } \\
\text { sex }\end{array}$} & \multicolumn{6}{|c|}{ Pleural effusion } & \multicolumn{2}{|l|}{$\begin{array}{l}\text { Characteristics of } \\
\text { arthritis }\end{array}$} & \multirow{2}{*}{$\begin{array}{l}\text { Clinical follow up after } \\
\text { thoracoscopy }\end{array}$} \\
\hline & $\begin{array}{l}\text { Protein } \\
(g / l)\end{array}$ & $\begin{array}{l}\text { Glucose } \\
(\mathrm{mg} / 100 \mathrm{ml})\end{array}$ & $\begin{array}{l}L D H \\
(U / l)\end{array}$ & $\begin{array}{l}R A \\
\text { cells }\end{array}$ & $\begin{array}{l}\text { Cholesterol } \\
\text { crystals }\end{array}$ & $\begin{array}{l}\text { Thoracocenteses/months } \\
\text { Volume of fuid (ml) } \\
\text { aspirated }\end{array}$ & $\begin{array}{l}\text { Interval (y) from arthritis } \\
\text { to thoracoscopy (pleurisy) }\end{array}$ & Stage* & \\
\hline $1 \mathrm{M}$ & 62 & 0 & 2000 & + & + & $\begin{array}{l}5 / 24 \\
3000\end{array}$ & 11 years $(L)$ & $\mathrm{C}$ & $\begin{array}{l}\text { Alive after } 10 \mathrm{y} \text { with } \\
\text { continuous activity of arthrit }\end{array}$ \\
\hline $2 \mathrm{M}$ & 49 & $\begin{array}{l}25 \\
10\end{array}$ & $\begin{array}{l}5840 \\
2400\end{array}$ & $\begin{array}{l}+ \\
+\end{array}$ & $\begin{array}{l}- \\
-\end{array}$ & $\begin{array}{l}9 / 36 \\
3950 \\
5 / 12 \\
800\end{array}$ & $\begin{array}{l}2 \text { years }(R) \\
5 \text { years }(L)\end{array}$ & $\mathrm{C}$ & $\begin{array}{l}\text { Alive after } 10 y \text { with } \\
\text { continuous activity of arthrit }\end{array}$ \\
\hline $3 \mathbf{M}$ & 62 & $\begin{array}{r}10 \\
0\end{array}$ & $\begin{array}{l}4500 \\
7500\end{array}$ & $\begin{array}{l}+ \\
+\end{array}$ & $\begin{array}{l}- \\
-\end{array}$ & $\begin{array}{l}4 / 24 \\
1300\end{array}$ & 11 years $(R)$ & $\mathrm{C}$ & $\begin{array}{l}\text { Died after } 8 \text { y of perforated } \\
\text { appendicitis }(N) \text { with } \\
\text { continuous activity of arthrit } \\
\text { time of death }\end{array}$ \\
\hline $4 \mathrm{~F}$ & 44 & 25 & 5720 & + & + & $\begin{array}{l}2 / 3 \\
1500\end{array}$ & 10 years $(R)$ & $\mathrm{C}$ & $\begin{array}{l}\text { Died after } 1 \text { y of pulmonary } \\
\text { embolus }(N) \text { with continuous } \\
\text { activity of arthritis at time of }\end{array}$ \\
\hline $5 \mathrm{M}$ & 44 & 30 & 7000 & + & + & $\begin{array}{r}2 / 12 \\
600\end{array}$ & 10 years $(L)$ & $\mathrm{C}$ & $\begin{array}{l}\text { Died after } 6 \text { y of acute myoc } \\
\text { infarction }(N) \text { with remission } \\
\text { arthritis }\end{array}$ \\
\hline $6 \mathrm{M}$ & 99 & 0 & 7200 & + & - & $3 / 9$ & 3 years $(L)$ & C & $\begin{array}{l}\text { Alive after } 10 y \text { with remissi } \\
\text { arthritis }\end{array}$ \\
\hline $7 F$ & $\overline{72}$ & $\overline{25}$ & $\overline{6200}$ & + & + & $\begin{array}{l}6 / 14 \\
2000 \\
4 / 12 \\
1100\end{array}$ & $\begin{array}{l}30 \text { years }(L) \\
33 \text { years }(R)\end{array}$ & $\mathrm{C}$ & $\begin{array}{l}\text { Alive after } 10 \mathrm{y} \text { with continu } \\
\text { activity of arthritis }\end{array}$ \\
\hline $8 M$ & 88 & 0 & 3200 & + & - & $\begin{array}{l}2 / 2 \\
800\end{array}$ & $-1 / 4$ year $(L)$ & D & $\begin{array}{l}\text { Alive after } 31 / 2 \text { y without act } \\
\text { of arthritis the last } 11 / 2 y\end{array}$ \\
\hline $9 \mathrm{M}$ & 50 & 83 & 1731 & + & - & $\begin{array}{c}1 / 1 \\
500\end{array}$ & $-1 / 12$ year $(L)$ & D & $\begin{array}{l}\text { Alive after } 1 \text { y with continuo } \\
\text { activity of arthritis }\end{array}$ \\
\hline Mean value & 63 & 19 & 4844 & & & $\begin{array}{l}4 / 14 \\
1500\end{array}$ & & & \\
\hline
\end{tabular}

${ }^{*} \mathrm{C}$-classical: D-definite.

LDH-lactate dehydrogenase; RA-rheumatoid arthritis: $\mathrm{N}$-Necropsy.

Conversion: traditional to SI units-Glucose: $1 \mathrm{mg} / 100 \mathrm{ml}=0.0555 \mathrm{mmol} / \mathrm{l}$.

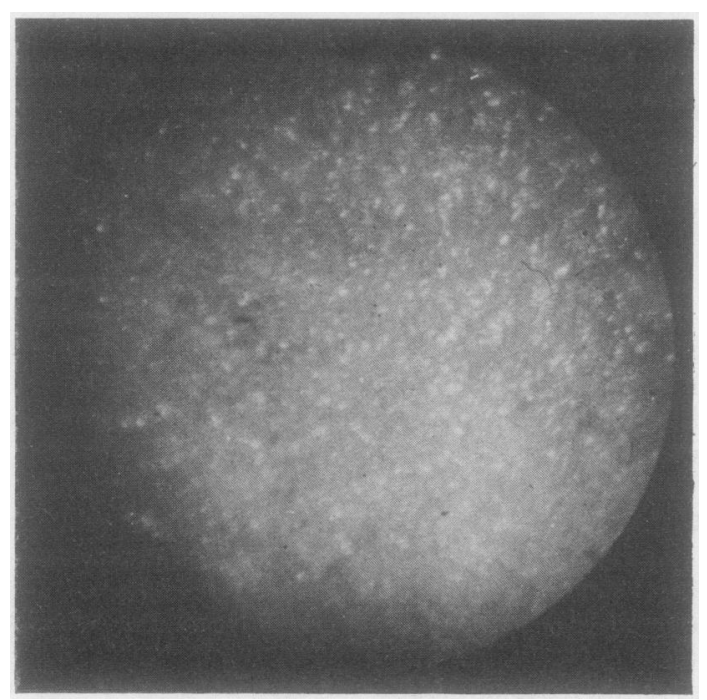

Fig 1 Thoracoscopic view of the costal parietal pleura in rheumatoid pleurisy, with a gritty, granular surface. Small granules are scattered all over the surface (patient 8). (fig 1). These granules were identified all over the parietal pleura in eight of our cases: in one case they were more unevenly distributed, being localised mostly in the upper lateral part of the costal pleura.

Thoracoscopy was performed without any serious complications. One patient required four days of pleural drainage to expand the lung.

HISTOPATHOLOGICAL CHANGES IN THE PLEURA The most constant finding was lack of a normal mesothelial cell covering. Instead a pseudostratified layer of epithelioid cells was seen, which focally formed multinucleated giant cells of a type different from those of Langerhans, as well as foreign body giant cells (figs 2 and 3 ). In several instances the epithelioid cell layer was found as membranes parted from the stroma. The stroma was fibrous and showed features of chronic focal inflammation, although it was only slightly infiltrated. There were no granulomas or necrosis. The luminal outline of this stroma appeared slightly wavy because of regular small papillae containing branching capillaries (figs 2 and 4 ). The size of these papillae and the distance between them $(0.1-0.5 \mathrm{~mm})$ were similar to 


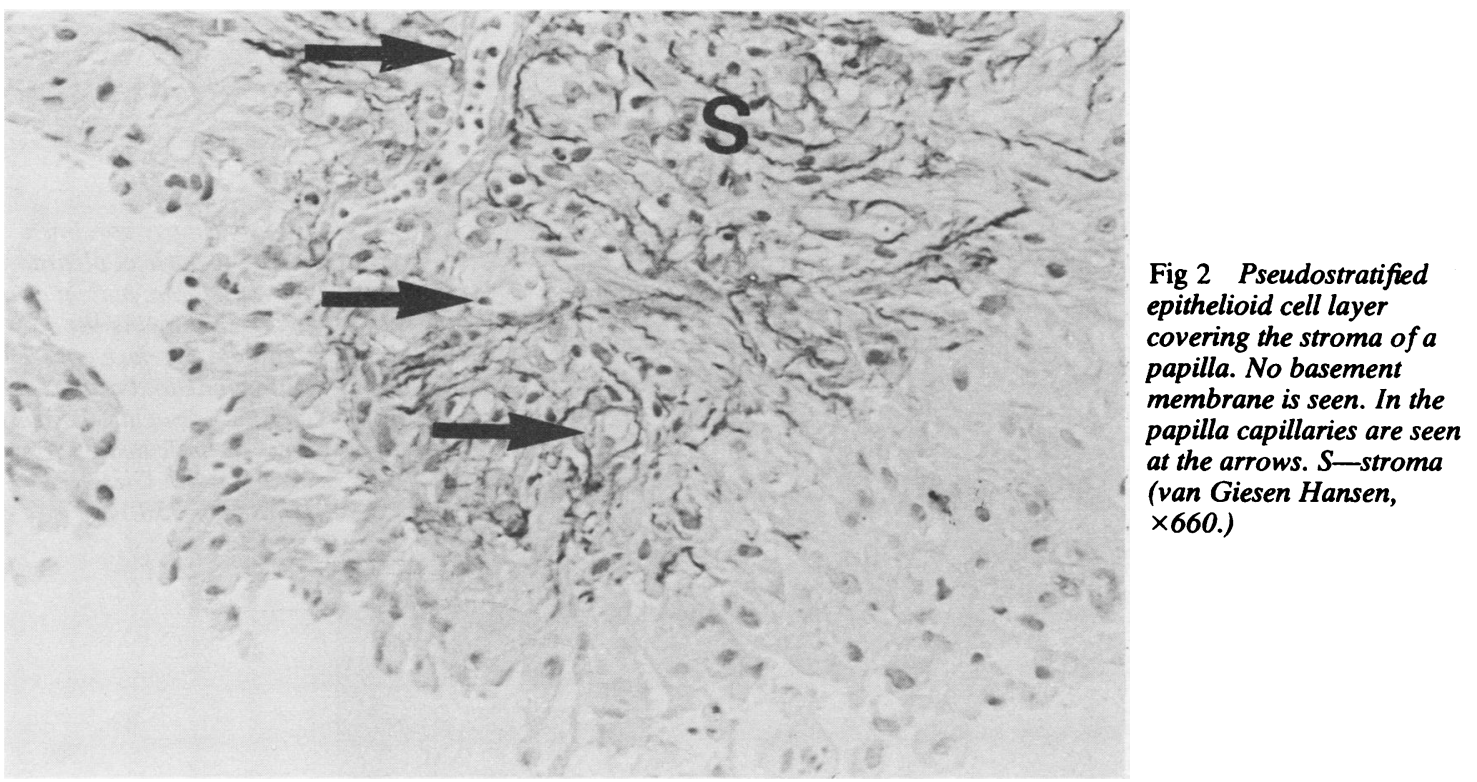

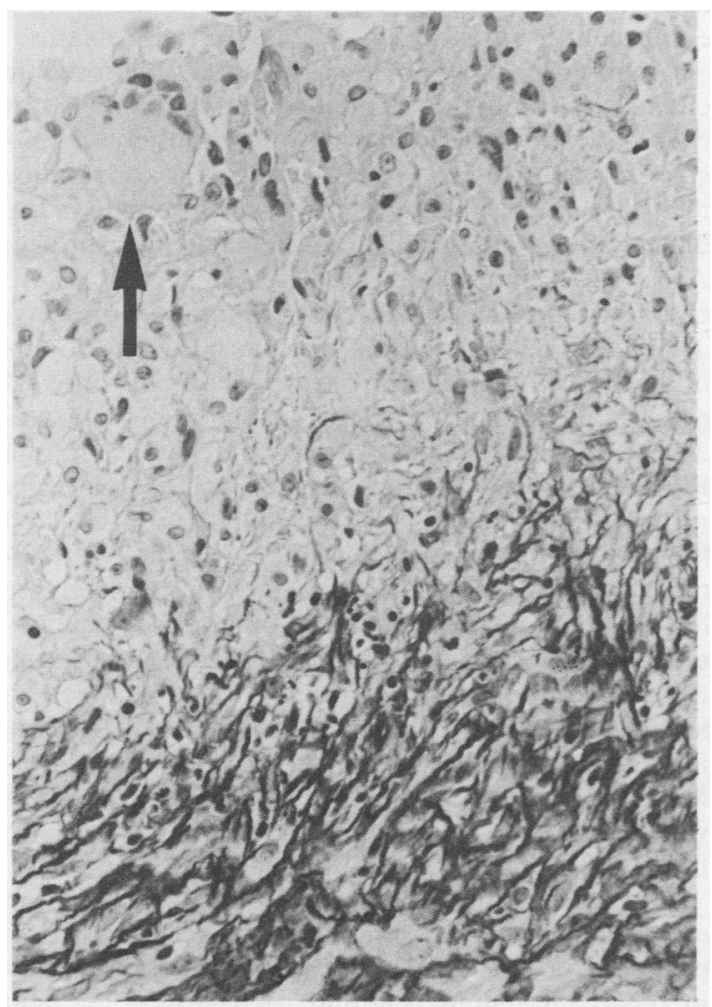

Fig 3 Giant cell (arrow) in the epithelioid surface cell layer. (van Giesen Hansen, $\times 580$.) those of the small granules identified thoracoscopically. The most characteristic histological appearance was found in the parietal pleural biopsy specimens from four of the patients. Scme of these features were found in the remaining parietal pleural biopsy specimens. In the four visceral pleural biopsy specimens only non-specific inflammatory changes were found.

THE PLEURAL FLUID

Macroscopically the fluid was cloudy, greenish yellow, opalescent, and non-odorous. In all cases an exudate was present (table) (mean value of protein content $63 \mathrm{~g} / \mathrm{l})$. The glucose concentration was low in eight patients (mean value $13 \mathrm{mg} / 100 \mathrm{ml}(0.72$ $\mathrm{mmol} / \mathrm{l})$ ) but in one case was as high as the blood glucose $(83 \mathrm{mg} / 100 \mathrm{ml}(4.6 \mathrm{mmol} / \mathrm{l}))$. The lactate dehydrogenase content was constantly high (mean value $4844 \mathrm{U} / \mathrm{l}$ ). In all cases RA cells were present. Cytological examination showed the presence of eosinophilic, amorphous material, cholesterol crystals, epithelioid cells, and scattered multinucleated giant cells. There were no tumour cells and all cuttures were negative for bacteria.

\section{CLINICAL COURSE OF RHEUMATO'D ARTHRITIS}

AND RHEUMATOID PLEURISY

The average period between the onset of arthritis and the pleurisy was 13 years for seven of the patients (table). Two patients had pleurisy as the first manifestation of the rheumatoid disease, fol- 


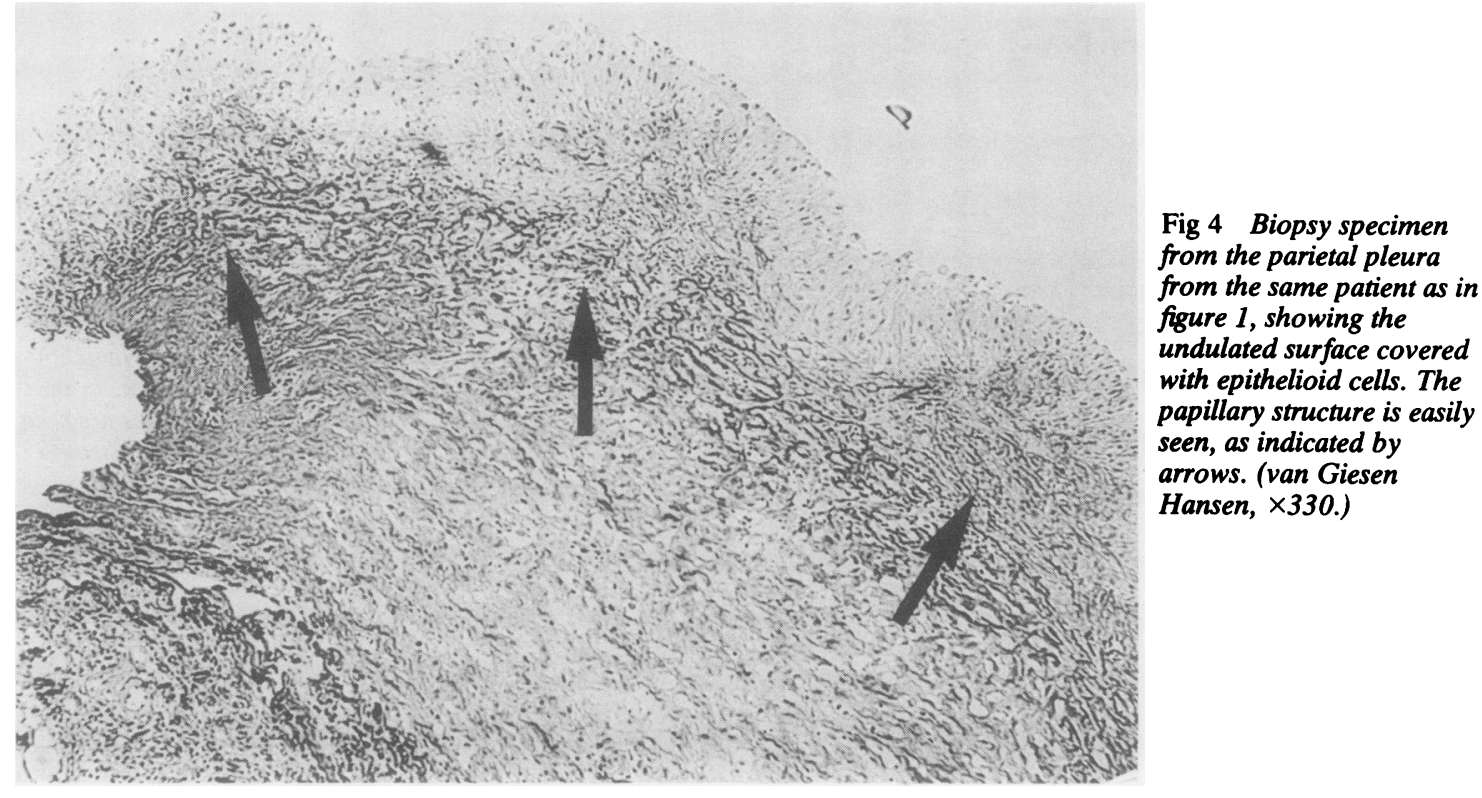

lowed by arthritis after one and three months respectively. The pleural effusion lasted an average of 14 months (range 1-36 months). The average number of thoracocenteses was four per patient (range 1-9). The mean value for the total amount of fluid removed was $1500 \mathrm{ml}$ per patient (range 500$3950 \mathrm{ml}$ ). In seven cases the pleurisy was unilateral. The remaining two patients each developed rheumatoid pleurisy on the contralateral side after an interval of three years.

Four patients with persistent rheumatoid arthritis were alive 10 years after thoracoscopy, showing no clinical or radiographic signs of pleural activity. Three patients with persistent rheumatoid arthritis died from intercurrent diseases one, six, and eight years after thoracoscopy. Patient 8 was alive after three years, having had remission of the arthritis over the last one and a half years. Patient 9 was alive after one year and suffered continuous activity of the rheumatoid arthritis.

\section{Discussion}

Thoracoseopy showed an identical and characteristic macroscopic appearance of the parietal pleura in all our nine patients. This appeararice was not seen in any other category of pleural disease,,$^{1314}$ and to our knowledge it has not been previously described in the literature except for one preliminary report in 1974.) $)^{9}$ The lack of specific thoracoscopic findings in two patients with rheumatoid pleural effusion reported by Jacobeaeus in $1925^{15}$ could possibly be

ascribed to the relatively primitive thoracoscopic equipment used as well as to diagnostic problems.

Champion et $a^{16}$ described the microscopic changes in rheumatoid pleurisy as an opened out rheumatoid nodule with palisading epithelioid cells covering the surface. We found a similar appearance in all of our cases that was most characteristic in the biopsy specimens from the parietal pleural surface. Aru et al ${ }^{17}$ claimed that the histological changes are characteristic and specific for rheumatoid pleurisy. There are several reasons for the absence of this observation among the reports on histological changes in rheumatoid pleurisy. The pleurisy is seldom acute and is most often treated with simple thoracocenteses. Thoracoscopy is still a relatively rarely used diagnostic tool, but may be useful when blind thick needle biopsies fail to provide a diagnosis. In our patients the absence of characteristic histological changes in material obtained by conventional biopsy could be explained by our observation that the epithelioid cell layer is so easily detached, leaving the denuded raw surface of the slightly inflamed stroma. Furthermore, the area of the luminal stromal surface in thick needle biopsy specimens will be too small for recognition of any regularity in the papillary formations.

The biochemical changes in the pleural fluid from our patients did not differ from those described in previous reports. In $80 \%$ the glucose concentration in the pleural fluid is found to be $\operatorname{low}^{2641814}$ and either high or in equilibrium with blood glucose concentration in the remaining cases. ${ }^{1019}$ This is also a 
finding, however, in tuberculous pleurisy and malignant diseases of the pleura. ${ }^{24}$ The lactate dehydrogenase concentration was high but this finding is also not specific. ${ }^{24}$ RA cells from the pleural fluid were found in all our patients, in accordance with other reports, ${ }^{3742021}$ but the RA cell is not specific for rheumatoid pleural effusion as this cell is also found in other diseases of the pleura. ${ }^{45} \mathrm{~A}$ unique cytological picture in rheumatoid pleural effusion has been reported. ${ }^{22-24}$ Moreover, these findings seem to be specific, as claimed by Engel et al. ${ }^{25}$ By the technique applied for the identification of the RA cells no abnormal cell types were observed in the cytological specimens in our series.

In our patients rheumatoid pleural effusion developed an average of 13 years after onset of the arthritis and the effusion resolved after an average of 14 months, but there was a great variation in this period (1-36 months), which is in accordance with the report of Walker et al. ' No treatment other than aspiration when clinically indicated was used and this accords with accepted practice. ${ }^{13}$ In no cases did the rheumatoid pleural effusion show simultaneous bilateral occurrence, although Walker et al' found a few patients with simultaneous bilateral rheumatoid pleurisy. In none of our patients were there serious complications after the rheumatoid pleurisy, but severe pleural changes necessitating decortication have been reported." $" 1$

In conclusion, rheumatoid pleurisy is at present a diagnosis reached only by exclusion, but the thoracoscopic granular appearance of the parietal pleura and the histopathological changes seem to be highly diagnostic and offer an important supplement to other laboratory data.

\section{References}

1 Walker WC, Wright V. Rheumatoid pleuritis. Ann Rheum Dis 1967;26:467-73.

2 Anonymous. Pleural effusion in rheumatoid arthritis. Lancet 1972; i:480-1.

3 Emerson P. Rheumatoid disease. In: Emerson P, ed. Thoracic medicine. London: Butterworth, 1981:610-2.

4 Faurschou P. Decreased glucose in RA cell positive pleural effusion. Eur J Respir Dis 1984;65:272-7.

5 Faurschou P, Faarup P. Granulocytes containing cytoplasmic inclusions in human tuberculous pleuritis. Scand J Respir Dis 1973;54:341-6.

6 Carr DT, Mayne JG. Pleurisy with effusion with reference to the low concentration of glucose in pleural fluid. Am Rev Respir Dis 1962;85:345-50.

7 Mandl MAJ, Watson JI, Henderson JAM, Wang NS. Pleural fluid in rheumatoid pleuritis. Arch Intern Med 1969; 124:373-6.

8 Heller P, Kellow WF, Chomet B. Needle biopsy of the parietal pleura. $N$ Engl J Med 1956;255:684-90.

9 Faurschou P. Rheumatoid pleuritis and thoracoscopy. Scand J Respir Dis 1974;55:277-83.

10 Sahn SA, Kaplan RL, Maulitz RM, Good JT jun. Rheumatoid pleurisy. Observations on the development of low pleural fluid $\mathrm{pH}$ and glucose level. Arch Intern Med 1980;140:1237-8.

11 Feagler JR, Sorenson GD, Rosenfeld MG, Osterland CK. Rheumatoid pleural effusion. Arch Pathol 1971;92:257-66.

12 Ropes MW, Bennet GA, Cobb S, Jacox R, Jessar RA. Revision of diagnositic criteria for rheumatoid arthritis. Arthritis Rheum 1958;2:16-20.

13 Enk B, Viskum K. Diagnostic throacoscopy. Eur J Respir Dis 1981;62:344-51.

14 Brandt HJ, Loddenkamper R, Mai J, Boutin Chr, Faurschou P, Viskum K, Rodgers BM. Atlas der diagnostischen Thorakoskopie. Stuttgart: Georg Thieme Verlag, 1983.

15 Jacobaeus HC. Die Thorakoskopie und ihre praktische Bedeutung. Ergen Gesamt Med 1925;7:112-66.

16 Champion GD, Robertson MR, Robinson RG. Rheumatoid pleurisy and pericarditis. Ann Rheum Dis 1968;27:521-30.

17 Aru A, Engel U, Francis D. Histological findings in rheumatoid pleurisy. In: Grundmann E, ed. Proceedings of the Ninth European Congress of Pathology, Hamburg 1983. Pathol Res Pract 1983;178:109.

18 Delcambre B, Siame JL, Tounel AB, Lafitte JJ, Duquesnoy B, Thevenon A, Tidjani O. Les pleuresies rhumatoides. Poumon Coeur 1980;47:621-9.

19 Pettersson T, Klockars M, Hellstrom P-E. Chemical and immunological features of pleural effusion: comparison between rheumatoid arthritis and other diseases. Thorax 1982;37:354-61.

20 Berger HW, Seehler SG. Pleural and pericardial effusions in rheumatoid disease. Ann Intern Med 1966;64: 1291-6.

21 Carmichael DS, Golding DN. Rheumatoid pleural effusion with "RA cells" in the pleural fluid. Br Med J 1967;ii:814.

22 Boddington MM, Spriggs AI, Morton A, Mowat AG. Cytodiagnosis of rheumatoid pleural effusions. J Clin Pathol 1971;24:95-106.

23 Morawertz F. Zytodiagnostik der rheumatischen Pleuritis. Internistische Praxis 1978;18:221-8.

24 Nosanchuck JS, Naylor B. A unique cytologic picture in pleural fluid from patients with rheumatoid arthritis. Am J Clin Pathol 1968;50:330-5.

25 Engel U, Aru A, Francis D. Cytological findings in rheumatoid pleurisy. In: Brux J, ed. Proceedings of the 12th European Congress of Cytology. Paris: European Federation of Cytology Societies, 101. 